\title{
Upgrading of Heavy Crude Oil with W-Zr Catalyst
}

\author{
P. Schacht1 ${ }^{*}$, L. Díaz-García1' J. Aguilar², S. Ramírez¹, P. Pérez-Romo¹, M. Espinosa1 \\ ${ }^{1}$ Instituto Mexicano del Petróleo, México D.F., México \\ ${ }^{2}$ Universidad Autónoma Metropolitana, División de Ciencias Básicas e Ingeniería, México D.F., México \\ Email: ${ }^{*}$ pschacha@imp.mx
}

Received 14 January 2014; revised 10 February 2014; accepted 8 February 2014

Copyright (C) 2014 by authors and Scientific Research Publishing Inc.

This work is licensed under the Creative Commons Attribution International License (CC BY). http://creativecommons.org/licenses/by/4.0/

(c) (i) Open Access

\section{Abstract}

The main problem of new crude oil reserves is the incipient increase of heavy crude oils in the American continent, i.e. USA, Mexico, Canada and Venezuela. These types of crude oils require several treatments before refining. One of these treatments can be hydrocracking. In this petroleum refining process, it is possible to modify the heavy crude oils to light crude oils. In this paper, we try to use hydrocracking to improve the quality of raw heavy crude oil, through some chemical transformations $\mathrm{C}-\mathrm{H}$ binding rupture using a catalyst containing active metals such as tungsten and zirconium (W-Zr). After the crude oil was hydrocracked in presence of this novel bimetallic catalyst, the hydrocracked products showed lower content of asphaltenes, resins, sulfur and nitrogen. Also positive changes in the viscosity of crude oil measured as a decreasing of this value were observed. The American Petroleum Institute (API) gravity was significantly increased 6 units. Consequently, all these changes confirmed that the upgrading of the heavy crude oil was successful.

\section{Keywords}

Heavy Crude Oil, Upgrading, Tungsten-Zirconium, Catalyst

\section{Introduction}

The International Energy Agency reported in 2009 that the demand for crude oil has increased over the last 40 years by $150 \%$ and, by $20 \%$ in the past two decades, to reach a current demand of 80 million barrels per day. It is projected to grow 1.4\% per year for the next 30 years and reach 118 million barrels per day by 2030 [1] [2]. This oil demand comes at time when there is a gradual reduction in the supply of relatively cheap conventional

${ }^{*}$ Corresponding author. 
crude and new discoveries of light field oil do not cover this demand [2] [3]. It is estimated that there are 8 - 9 trillion barrels of heavy crude oil and bitumen around the world, of which potentially 900 billion barrels of crude oil are commercially exploitable with modern technology [3]-[5]. In 2015, the growth of oil sand exploitation will exceed 2 to 3 times than the conventional crude oil production. Moreover, better methods are needed to upgrade partially the heavy crude oil before further processing in refineries in order to convert it into light crude oil [4]-[7].

In the catalytic hydrocracking of heavy crude oil, it is necessary to snap the asphaltenes, because they are extremely large molecules. These molecules consist of highly condensed material, heterocyclic and aromatic rings containing sulfur, nitrogen, oxygen, and metals (mainly vanadium and nickel). Therefore, some of the catalysts for hydrogenation contain nickel, tungsten, molybdenum, cobalt or zirconium [8] [9]. For example, molybdenum, tungsten and nickel are widely used as catalysts in refining processes such as hydrocracking, hydrodesulphurization and hydrodenitrogenation. These catalysts are supported on porous materials like crystalline alumina [10].

Moreover, the acid-base properties of these catalysts may help to increase the yield of gasoline and other light hydrocarbons in crude oil processing and also to produce environmentally friendly products [9]-[14].

The purpose of this work is to study the behavior of an acid catalyst formulated with tungsten and zirconium, in the upgrading of the properties of a heavy crude oil. The study of viscosity decreasing and the changes in structural composition of heavy crude oil after the reaction were analyzed [15]-[17]. The paper also examines the decreasing of asphaltenes, resins, sulfur and nitrogen compounds and the increase of API gravity.

\section{Experimental Section}

\subsection{Preparation of Catalyst}

The active elements of this catalyst are zirconium, tungsten and oxygen. 5 grams of $\mathrm{ZrOCl}_{2} \cdot 8 \mathrm{H}_{2} \mathrm{O}$ (Aldrich 99\%) were dissolved in $300 \mathrm{~mL}$ of water using a beaker; the content was stirred at room temperature. A solution of 15 grams of $\mathrm{Na}_{2} \mathrm{WO}_{4} \cdot 2 \mathrm{H}_{2} \mathrm{O}$ (FLUKA 98\%) in $100 \mathrm{~mL}$ of water was also prepared and added to the solution of $\mathrm{ZrOCl}_{2} \cdot \mathrm{H}_{2} \mathrm{O}$. The resulting solution immediately turned turbid. After stirring this solution for about 30 minutes, $200 \mathrm{ml} 1 \mathrm{~N}$ of $\mathrm{HCl}$ (MERICHEM 37\%) was also added and the mixture was stirred for one more hour and allowing it to stand still overnight at room temperature. The precipitate formed was separated by filtration.

\subsection{Activity Tests}

The activity tests were carried out in a Parr batch reactor. During the experiments, $200 \mathrm{~g}$ of heavy oil were mixed with $5 \mathrm{~g}$ of the W-Zr catalyst. Before each experimental test, the reactor was purged with $\mathrm{H}_{2}$ and stabilized at the required reaction pressure, temperature and stirring rate. The hydrogen pressure was increased to $10.8 \mathrm{MPa}$, and the reactor was heated to the reaction temperature of $653 \mathrm{~K}$, at $1000 \mathrm{rpm}$. Three reaction times were evaluated 30, 45 and 60 minutes, the product samples were recovered at the end of each test. The physical and chemical properties of the products from heavy oil upgrading were characterized in accord to the ASTM methods.

\subsection{Characterization}

Thermogravimetric analyses (TGA-DTA) were obtained with a Perkin-Elmer 1700. The nature of the acid sites of catalyst was analyzed by Pyridine thermo desorption-FTIR, using a spectrophotometer Nicolet FTIR Magna 560. A quartz cell was used for infrared spectrometry with $4 \mathrm{~cm}^{-1}$ of resolution, using $\mathrm{KBr}$ as blank. Temperature programmed reduction was carried out in an equipment AMI-200 ZETON-Altamira coupled to thermal conductivity detector (TCD) using a certified gases mixture, 10 vol-\% of Hydrogen in Argon from $303 \mathrm{~K}$ to $1123 \mathrm{~K}$ with heating rate of $10 \mathrm{~K} / \mathrm{min}$ and recording the changes in sample with thermal conductivity detector. The detector calibration was carried out at $313 \mathrm{~K}$ using a $57 \mathrm{uL}$ loop. In order to characterize the metallic sites of this $\mathrm{W}$-Zr liquid phase catalyst, this was supported on inert alumina, dried at $383 \mathrm{~K}$ in air static atmosphere during 4 hours before $\mathrm{H}_{2}$-TPR. Physical and chemical properties of heavy oil and products were characterized. API gravity was measured according ASTM-D-287 method. The viscosity was determined using a rotary viscometer; heavy crude oil was put into a sample cup and kept at 298, 310 and $327 \mathrm{~K}$ over $20 \mathrm{~min}$, then measurement was conducted according to ASTM-D445 method. SARA analysis (saturates, aromatics, resins and as- 
phaltenes) were determined by ASTM-D-4124 method. Sulfur content in the crude oil was measured by ASTMD4294 method.

\section{Results and Discussion}

The catalyst W-Zr was characterized using the solid precursor's mechanical mixture in order to obtain the thermal transformations by TGA and DTA.

\subsection{Thermogravimetric Analysis}

The DTA and TGA plots of catalyst are shown in Figure 1 and Figure 2 respectively. The obtained results showed that the catalyst weight is reduced which depends, in part of the composition of the sample [18] [19].

In a first zone, the catalyst showed changes at temperatures in the range of $298-373 \mathrm{~K}$. The weight loss was about $3.6 \mathrm{wt} \%$ and it was attributed to the removal of fisisorbed water. These are stable octahedral structures of $\mathrm{H}_{2} \mathrm{O}$ molecules that form hydrogen bonds with the acid protons.

In a second stage the weight loss was $33.6 \mathrm{wt} \%$ and occurred between 388 and $585 \mathrm{~K}$ and corresponded to the removal of crystallization water that leads to the formation of anhydrous species such as $\mathrm{Na}_{2} \mathrm{WO}_{4}$ and $\mathrm{ZrOCl}_{2}$. These two stages showed different mass loss; both are highly endothermic [20].

The third stage is characterized by the decomposition of the tungstic acid which occurs with great difficulty. A weight loss of $6.2 \mathrm{wt} \%$, between 585 and $613 \mathrm{~K}$, attributed to the destruction of stable bonds in this volatile

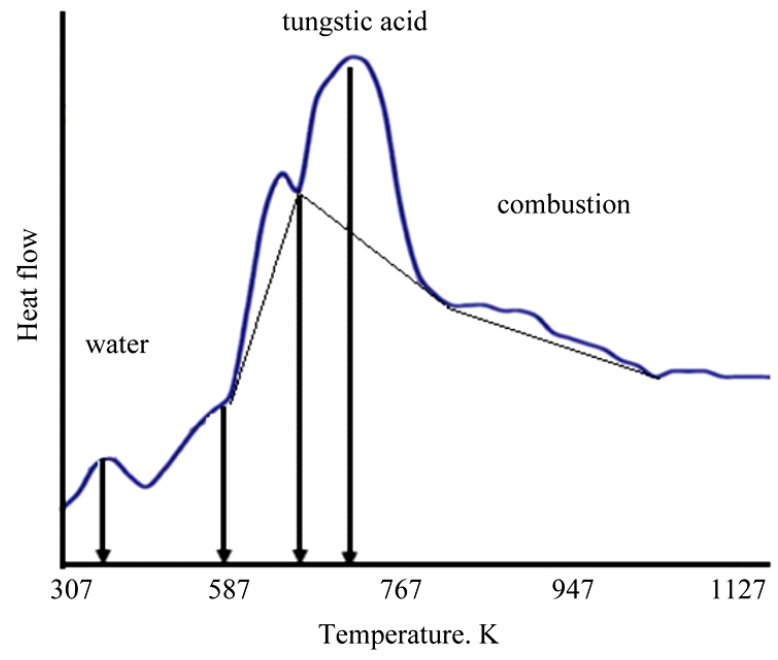

Figure 1. DTA curve for W-Zr catalyst.

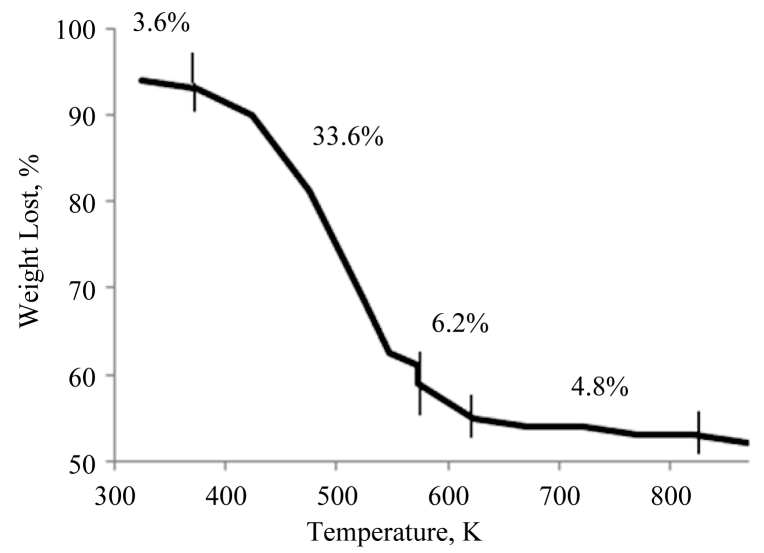

Figure 2. TGA curve for W-Zr catalyst. 
compound. The maximum rate of mass loss and DTA curve shifts to a positive zone, above the baseline, which confirmed an exothermic process, see Table 1.

The fourth stage was also characterized by small variations in rate and weight loss of $4.8 \mathrm{wt} \%$ between 613 and $803 \mathrm{~K}$, which was attributed to the breaking of binding metal-chlorides. All reactions were highly exothermic, during the increment of the temperature in the analysis.

The mass loss was related to the following stages, according to the enthalpy changes observed by DTA: 1) desorption of fisisorbed water before $383 \mathrm{~K} ; 2$ ) at $388 \mathrm{~K}$ removal of crystallization water leading to anhydrous species such as $\mathrm{Na}_{2} \mathrm{WO}_{4}$ and $\mathrm{ZrOCl}_{2}$; 3) decomposition of tungstic acid between 585 and $613 \mathrm{~K}$ and 4) oxidation of remaining $\mathrm{Cl}-\mathrm{Zr}$ and $\mathrm{Cl}-\mathrm{W}$ species, breaking the bindings of metal-chlorides between 613 and $803 \mathrm{~K}$ [21].

\subsection{Pyridine Thermo Programmed Desorption (TPD) by FTIR}

The IR spectroscopy is widely used to detect adsorbed pyridine and to distinguish different acid sites. FTIR pyridine adsorption spectra at $298 \mathrm{~K}$ and the spectra of TPD at 373, 473 and $523 \mathrm{~K}$ of W-Zr catalyst were shown in Figure 3. The spectra showed a sharp pyridine absorption-desorption bands at 1487, 1539, 1628 and $1643 \mathrm{~cm}^{-1}$. Pyridine molecules bonded to Lewis acid sites absorb at 1604 and $1444 \mathrm{~cm}^{-1}$, whereas those responsible for Brönsted acid sites (pyridinium ion) showed absorbance at 1539 and $1628 \mathrm{~cm}^{-1}$ [22]. The band at $1487 \mathrm{~cm}^{-1}$ is a combined band originated from pyridine bonds to both Brönsted and Lewis acid sites. Table 2 shows the Bronsted acid sites, while Figure 3 shows the FTIR pyridine TPD at different temperatures which could be confirmed elsewhere [23] [24].

Table 1. DTA and TG results for W-Zr catalysts.

\begin{tabular}{ccc}
\hline Temperature, $\mathbf{K}$ & Weight Loss, wt \% & Thermal Process \\
\hline $298-373$ & $3.6 \%$ & Endothermic \\
$388-585$ & $33.6 \%$ & Exothermic \\
$585-613$ & $6.2 \%$ & Exothermic \\
$613-803$ & $4.8 \%$ & Exothermic \\
TOTAL & $48.2 \%$ & Highly Exothermic \\
\hline
\end{tabular}

Table 2. Brönsted acid sites at different temperatures for $\mathrm{W}-\mathrm{Zr}$ catalyst.

\begin{tabular}{cc}
\hline Temperature, K & Brönsted (a.u.) \\
\hline 523 & 4.923 \\
473 & 5.180 \\
373 & 6.628 \\
298 & 6.458 \\
\hline
\end{tabular}

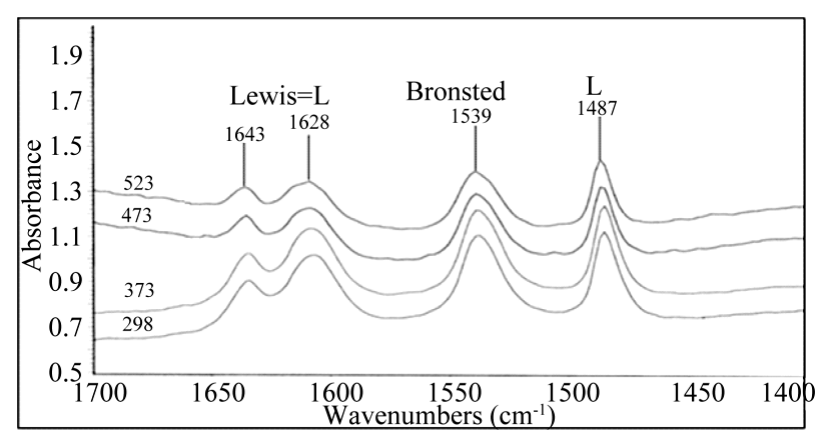

Figure 3. Acid sites distribution using pyridine TPD-FTIR of $\mathrm{W}-\mathrm{Zr}$ catalyst. 


\subsection{Temperature Programmed Reduction ( $\mathrm{H}_{2}$-TPR)}

The W-Zr catalyst was analyzed by Hydrogen TPR, starting the experiment at $303 \mathrm{~K}$, calibrating at zero the signal of TCD. Two main reduction profiles are shown in Figure 4, one first peak observed with a maximum temperature at $837 \mathrm{~K}$ attributed to the tetragonal and monoclinic phases of zirconia reduction. And the second peak profile was shown with a maximum reduction temperature of $1039 \mathrm{~K}$ attributed to tungsten species reduction of higher hydrogen consumption, with $78.5 \%$ of total reduction obtained (see Table 3). In accord to these reduction results the active sites of $\mathrm{W}-\mathrm{Zr}$ catalyst are able to hydrogenate heavy crude oil, considering the reaction temperature is possible that the influence of zirconia can be higher than tungsten in this catalyst.

\subsection{Viscosity and API Gravity of Upgrading Products}

After the reaction, the API gravity was increased from $12^{\circ}$ to $16^{\circ}$ and $18^{\circ}$, because of hydrocraking of resins and asphaltenes. Consequently, the kinematic viscosity was reduced from 15,416 to $391 \mathrm{cSt}$ at $298 \mathrm{~K}$, because of the production of smaller molecular weight structures. Increasing reaction time from 30 minutes to 45 and 60 minutes improved the reaction products quality and a similar behavior was reported elsewhere [25]. The Table 4 and Figure 5 show the API gravity increment, after the hydrocracking.

\subsection{Effects on the Composition of the Heavy Crude Oil}

SARA analyses (saturates, aromatics, resins and asphaltenes) of the heavy crude oil sample, shows that this sample contains 19, 22.5, 33.5 and $25 \mathrm{wt} \%$, of each group of S, A, R and A respectively. After reaction, it was

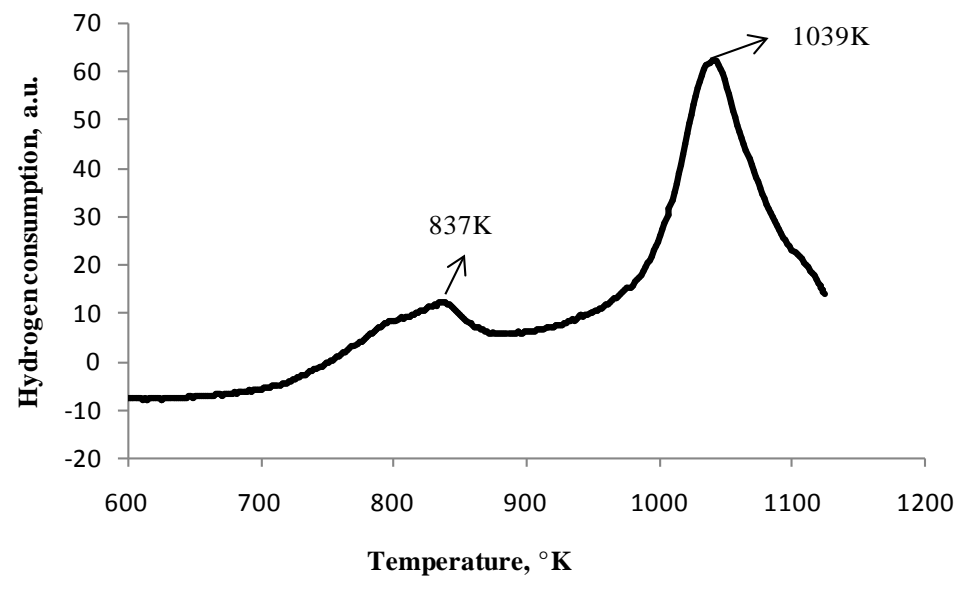

Figure 4. Temperature programmed reduction of the W-Zr catalyst.

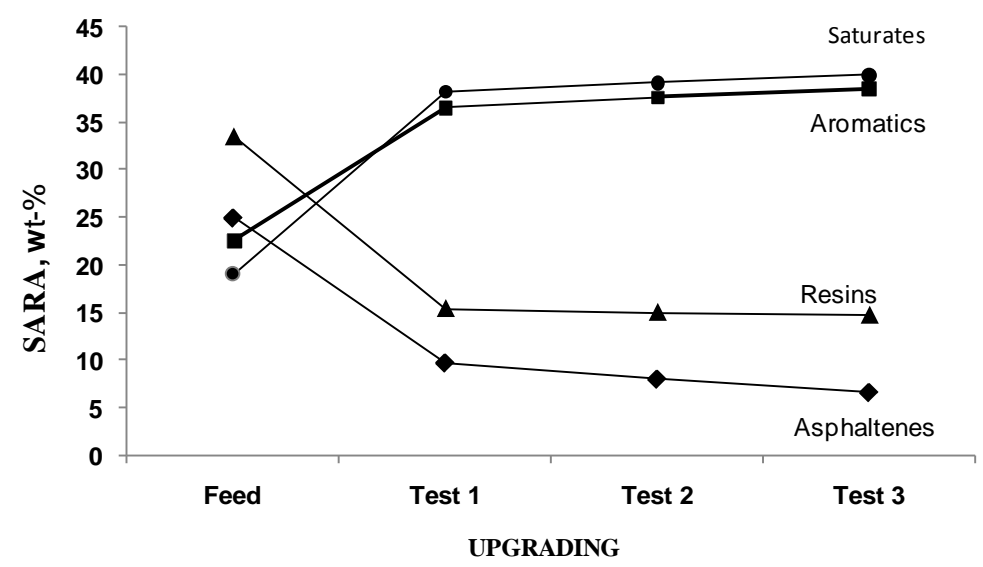

Figure 5. Effect of catalysts W-Zr on the hydrocarbon composition of heavy oil. 
Table 3. Physical and chemical properties of the heavy crude oil and the products.

\begin{tabular}{|c|c|c|c|c|c|}
\hline \multirow[b]{2}{*}{ Properties } & & \multirow[t]{2}{*}{ Heavy crude oil } & \multirow{2}{*}{$\begin{array}{c}\text { Test } 1 \\
30 \text { minutes }\end{array}$} & \multirow{2}{*}{$\begin{array}{c}\text { Test } 2 \\
45 \text { minutes }\end{array}$} & \multirow{2}{*}{$\begin{array}{c}\text { Test } 3 \\
60 \text { minutes }\end{array}$} \\
\hline & & & & & \\
\hline API & & 12.5 & 15.3 & 16.7 & 19.0 \\
\hline \multirow[t]{3}{*}{ Viscosity, cSt (K) } & @298.0 & 15,416 & 391 & 136 & 84 \\
\hline & @310.8 & 9897 & 278 & 100 & 60 \\
\hline & @327.4 & 5635 & 185 & 68 & 49 \\
\hline \multicolumn{2}{|c|}{ Sulfur, wt\% } & 5.13 & 3.4 & 3.1 & 2.8 \\
\hline \multicolumn{2}{|c|}{ Nitrogen, wt\% } & 0.78 & 0.69 & 0.64 & 0.62 \\
\hline \multicolumn{6}{|c|}{ SARA } \\
\hline \multicolumn{2}{|c|}{ Saturates, wt\% } & 19.0 & 38.2 & 39.1 & 40.0 \\
\hline \multicolumn{2}{|c|}{ Aromatics, wt $\%$} & 22.5 & 36.5 & 37.7 & 38.5 \\
\hline \multicolumn{2}{|c|}{ Resins, wt\% } & 33.5 & 15.5 & 15.1 & 14.8 \\
\hline \multicolumn{2}{|c|}{ Asphaltenes, wt\% } & 25.0 & 9.8 & 8.1 & 6.7 \\
\hline
\end{tabular}

Table 4. Hydrogen consumption of the reducible species for W-Zr catalyst.

\begin{tabular}{ccc}
\hline Total & First Peak & Second Peak \\
\hline Hydrogen consumption & Zirconia reduction & Tungsten reduction \\
106.00 milimoles $\mathrm{H}_{2}$ & 22.75 milimoles $\mathrm{H}_{2}$ & $83.25{\text { milimoles } \mathrm{H}_{2}}$ \\
\hline
\end{tabular}

observed that there is an increment in the saturated hydrocarbons and aromatic as a result of conversion of resins and asphaltenes, the asphaltenes content was also reduced. These results are in agreement with previous reports [25].

The results obtained indicate several effects of the catalysts in the upgrading of the heavy oil. For example the analysis by families of hydrocarbons reveals that the asphaltene declined, approximately 67 wt $\%$ of these were converted to lighter hydrocarbons. On the other hand, the concentration of aromatics was increased from 22.5 in original oil to 36.5, 37.7 and $38.5 \mathrm{wt} \%$, for the reaction times of 30, 45 and 60 minutes, respectively.

\subsection{Effects on Content Sulfur and Nitrogen}

The catalyst showed a high activity in the removal of sulfur of around 45 wt\%. However, sulfur removal also depends on the type of the feed and the operating conditions, which were not severe in the present test. This high catalytic activity can be explained by the total acidity of the catalyst and the hydrocracking properties of the transition metals $\mathrm{W}$ and $\mathrm{Zr}$ [26]. The sulfur content in the heavy oil was removed up to 3.4, 3.1 and $2.8 \mathrm{wt} \%$, at reaction times of 30, 45 and 60 minutes, respectively. The sulfur removal is caused by the scission of $\mathrm{C}-\mathrm{S}$ bonds as explained by the removal of thiophenic sulfur using the transition metal salts [27] [28]. These last results showed that the distribution of compounds changed with the increment of reaction time, confirming that this change was due to the conversion of the molecules of resins and asphaltenes.

On the other hand, the content of nitrogen after reaction was reduced from $0.78 \%$ wt in the original oil to 0.69 wt\% at $30 \mathrm{~min}, 0.64 \mathrm{wt} \%$ at $45 \mathrm{~min}$, and $0.62 \mathrm{wt} \%$ at 60 minutes [27] [28]. The nitrogen removal was approximately $20 \mathrm{wt} \%$. Table 4 summarizes the effect of the catalyst on the nitrogen content.

\section{Conclusion}

The hydrocracking and hydrogenation capability of the catalyst were responsible for the upgrading of heavy oil. The mild operating conditions in the present test were confirmed by the yields, and higher quality of the upgraded crude oil was obtained. The use of W/Zr catalysts is an interesting alternative for the upgrading of heavy crude oils. These catalysts showed high activity at three different residence times and achieved upgraded products with higher API gravity, lower kinematic viscosity, and lower content of sulfur, resins and asphaltenes. 


\section{References}

[1] Kjarstad, J. and Johnsson, F. (2009) Resources and Future Supply of Oil. Energy Policy, 37, 441-464.

[2] Laherrere, J. (2003) Forecast of Oil and Gas Supply to 2050. PETROTECH 2003, New Delhi.

[3] Isaacs, E. (2006) Book Canadian Oil Sands: Development and Future Outlook. Managing Director, Alberta Energy Research Institute, Canada’s National Energy Board, Calgary. http://www.asponews.org, http://www.energiekrise.de

[4] Fumoto, E. Tago, T., Tsuji, T. and Takao, M. (2004) Recovery of Useful Hydrocarbons from Petroleum Residual Oil by Catalytic Cracking with Steam over Zirconia-Supporting Iron Oxide Catalyst. Energy Fuels, 18, 1770-1774.

[5] Brian, C., Gordon, J. and Graves, W. (2007) Heavy Oil, Extra-Heavy Oil and Bitumen Unconventional Oil. National Petroleum Council Heavy Oil Subgroup of the Technology Task Group of the NPC Committee on Global Oil and Gas. http://www.npc.org/Study_Topic_Papers/22-TTG-Heavy-Oil.pdf

[6] Greene, D.L., Hopson, L. and Li, J. (2006) Have We Run out of Oil Yet? Oil Peaking Analysis from an Optimist’s Perspective. Energy Policy, 34, 515-531.

[7] Söderbergh, B., Robelius, F. and Aleklett, K. (2007) A Crash Programme Scenario for the Canadian Oil Sands Industry. Energy Policy, 35, 1931-1947.

[8] Mitsunori, S., Yoshlml, S. and Chlrato, T. (1986) Effect of Catalyst Pore Structure on Hydrotreating of Heavy Oil. Industrial \& Engineering Chemistry Fundamentals, 25, 330-337.

[9] Nor, A.L., Nilofar, A., Mohd, A.R. and Ali, A.B (2008) Investigation of Nanoscale Tungsten (VI) Oxide as a Catalyst for the Ozonolysis of Oleic Acid. European Journal of Inorganic Chemistry, 24, 463-467.

[10] Díaz-Garcia, L., Cortez, M.T., et al. (2006) Influence of Alumina Crystal Size on the Hydrotreating Activity of Supported NiMo Catalysts Using Real Feedstock. Petroleum Science and Technology, 24, 485-506.

[11] Supothina, S., Seeharaj, P., Yoriya, S. and Sriyudthsak, M. (2007) Synthesis of Tungsten Oxide Nanoparticles by Acid Precipitation Method. Ceramics International, 33, 931-936. http://dx.doi.org/10.1016/j.ceramint.2006.02.007

[12] Benitez, V.M., Yori, J.C., Grau, J.M., Pieck, C.L. and Vera, C.R. (2006) Hydroisomerization and Cracking of $n$-Octane and $n$-Hexadecane over Zirconia Catalysts. Energy \& Fuels, 20, 422-426. http://dx.doi.org/10.1021/ef050092j

[13] Bianchini, C., Jiménez, M.V., Meli, A., Moneti, S., Patinec, V. and Vizza, F. (1997) Mimicking the HDS Activity of Promoted Tungsten Catalysts. A Homogeneous Modeling Study Using a Two-Component Tungsten/Rhodium System. Organometallics, 16, 5696-5705. http://dx.doi.org/10.1021/om970711e

[14] Alhulmaidan, F., Haitham, M.S. and Al-Adwani, H. (2010) Hydrocracking of Atmospheric Residue Feedstock in Hydrotreating Processes. Kuwait Journal of Science, 37, 129-159.

[15] Welz, B. and Sperling, M. (2007) Frontmatter. In: Atomic Absorption Spectrometry, 3rd Edition, Wiley-VCH Verlag GmbH, Weinheim.

[16] Hsu, C.H., Chang, C.C., Tseng, C.M., Chan, C.C., Chao, W.H., Wu, Y.R., Wen, M.H., Hsieh, Y.T., Wang, Y.C., Chen, C.L., Wang, M.J. and Wu, M.K. (2013) An Ultra-Fast Response Gasochromic Device for Hydrogen Gas Detection. Sensors and Actuators B: Chemical, 186, 193-198. http://dx.doi.org/10.1016/j.snb.2013.06.004

[17] Valigi, M., Gazzoli, D., Pettiti, I., Mattei, G., Colonna, S., De Rossi, S. and Ferraris, G. (2002) $\mathrm{WO}_{\mathrm{x}} / \mathrm{ZrO}_{2} \mathrm{Catalysts:}$ Part 1. Preparation, Bulk and Surface Characterization. Applied Catalysis A: General, 231, 159-172. http://dx.doi.org/10.1016/S0926-860X(02)00050-9

[18] Baker, J.E., Burch, R. and Golunski, S.E. (1989) Thermal analysis of catalyst surfaces. Acta, 329-342.

[19] Haines, P.J. (2002) Principles of Thermal Analysis and Calorimetry. Royal Society of Chemistry, London, 220 p.

[20] China, H., Campbell, S. and Kesler, O. (2007) Thermal and Electrochemical Stability of Tungsten Carbide Catalyst Supports. Journal of Power Sources, 164, 431-440.

[21] Brostow, W., Menard, K.P. and Menard, N. (2009) Combustion Properties of Several Species of Wood. Chemistry \& Chemical Technology, 3, 173-176.

[22] Busca, G. (1998) Spectroscopic Characterization of the Acid Properties of Metal Oxide Catalysts. Catalysis Today, 41, 191-206. http://dx.doi.org/10.1016/S0920-5861(98)00049-2

[23] Kim, T.Y., Sung, D., Choi, Y., Baek, J., Park, J.R. and Yi, J. (2012) Preparation and Characterization of Mesoporous $\mathrm{Zr}-\mathrm{WO}_{\mathrm{x}} / \mathrm{SiO}_{2}$ Catalysts for the Esterification of 1-Butanol with Acetic Acid. Journal of Materials Chemistry, 22, 10021-10028. http://dx.doi.org/10.1039/c2jm30904a

[24] Lebarbier, V. and Clet, G. (2006) A Comparative Study of the Surface Structure, Acidity, and Catalytic Performance of Tungstated Zirconia Prepared from Crystalline Zirconia or Amorphous Zirconium Oxyhydroxide. Journal of Physical Chemistry B, 110, 13905-13911. http://dx.doi.org/10.1021/jp0571224

[25] Wang, H., Wu, Y., He, L. and Liu, Z. (2012) Supporting Tungsten Oxide on Zirconia by Hydrothermal and Impregna- 
tion Methods and Its Use as a Catalyst to Reduce the Viscosity of Heavy Crude Oil. Energy \& Fuels, 26, 6518-6527.

[26] Joonaki, E., Ghanaatian, Sh. and Zargar, Gh. (2012) A New Approach to Simultaneously Enhancing Heavy Oil Recovery and Hindering Asphaltene Precipitation. Iranian Journal of Oil \& Gas Science and Technology, 1, 37-42.

[27] Rana, M., Samano, V., Ancheyta, J. and Diaz, J.A. (2007) A Review of Recent Advances on Process Technologies for Upgrading of Heavy Oils and Residua. Fuel, 86, 1216-1231. http://dx.doi.org/10.1016/j.fuel.2006.08.004

[28] Lee, D.K. and Yoon, W.L. (1998) Modification of the Alumina-Supported Mo-Based Hydrodesulfurization Catalysts by Tungsten. Catalysis Letters, 53, 193-198. 